\title{
THE SIGNIFICANCE OF ROMAN LAW IN THE HISTORY OF INTERNATIONAL LAW *
}

\section{By Arthur Nussbaum $\dagger$}

Roman law, as generally conceived by the legal community, is private law-the law concerned essentially with property, contracts and family relations. Justinian's Corpus Juris (533-534 A. D.) contains in the Code, it is true, a good deal of Roman public law, and because of its exaltation of imperial power, this segment of Roman law supplied authority and juridical tools to the rising absolutism in the Sixteenth and Seventeenth Centuries; but otherwise the significance of Roman public law is virtually confined to the political and legal history of the ancient Roman Empire. With international relations the Corpus Juris itself has practically nothing to do. An exception is the recognition of the sanctity (not the "extraterritoriality") of envoys; to beat them was declared a violation of the law (jus gentium) ${ }^{1}$-an acknowledgment that the rule was by no means specifically Roman. On the other hand the Corpus Juris and especially its main part, the Digest, does not much discriminate against non-Romans-a liberal attitude unknown to other ancient nations including the Greeks, ${ }^{2}$ and unknown even to the Middle Ages.

\section{Legal Elements in Roman Foreign Affairs}

Outside the Corpus Juris, we have knowledge, through legal and historical sources, of rules of ancient Rome's municipal law touching international relations-so-called "external" municipal law. The law of booty in war is an instance. ${ }^{3}$ Such booty was to be delivered to the

* The subject of the present article has not yet been made the basis of any special study as far as the writer knows. Hrabar, The Roman Law In the History of International Doctrine (Dorpat 1901, in Russian) is exclusively concerned with private international law; see the summary in REvUE DE DROIT INTERNATIONAL ET DE LEGisLATION COMPAREE 1902, 458. In the early history of private international law the permanent influence of Roman legal doctrine is quite obvious, but with this matter we are not concerned here. Nor does the thoughtful study by Koschaker, EuRopa und das Römische REcht (1947), touch upon the development of. international law.

$\dagger$ Research Professor of Public Law, Columbia University (Ret.). Professor of Law, University of Berlin, 1918-1933. Author of MONEy IN THE LAW (1939), Principles of Private International Law (1943), Concise History of the Law of Nations (1947), Money in the Law, National and International (1950), American-Swiss Private International Law (1951).

1. Digest 50.7.18 (Pomponius), "Si quis legatum hostium pulsassit, contra jus gentium id commissum esse existimatur, quia sancti habentur legati."

2. See Nussbaum, Concise History of the Law of Nations 11 (1947).

3. See Bluntschli, Das Beuterecht im Kriege 26 (1878); Lüder, Landkriegsrecht im Besonderen in 4 HOLTZENDORFF, HANDBUCH DES VöLKERRECHTS 423, 489 (1889). 
quaestores, government officials who would distribute either the captured objects or their proceeds from public sale, one portion being reserved for the treasury. This regulation, born of Roman sense of military discipline, contrasts favorably with the custom found not only with barbarians, but also with ancient Greece and within medieval Western Europe. According to that custom, booty, including prisoners of war, became the captor's personal property.

The most signal part of Roman "external" law, however, is the archaic jus fetiale (or feciale), a body of sacramental rules developed by a special group of priests, the fetiales. ${ }^{4}$ The latter were entrusted with the administration of religious ceremonials used in treaty-making, war and other international matters, such as legation and extradition. Toward the end of the Republic the authority and the functions of the fetiales faded, and only fragments of these rules have come down to us. Most memorable was their participation in the grave decision whether the Romans should begin a war. In a solemn and formalized procedure they would decide whether a war would be "just" and "pious"-bellum justum et pium-so as to be favored by the gods; the ultimate decision on the waging of a war was left to the Senate and the people. That particular feature of jus fetiale probably belongs to a very early phase of the Republic, ${ }^{5}$ but indirectly, as will be seen, it assumed a lasting significance.

Passing from municipal "external" law to real international law, we find that Rome did participate to some extent in the formation of the latter. ${ }^{-}$The recognition of the inviolability of envoys has already been mentioned. More important were the compacts which Rome concluded with foreign nations. Most of these agreements exhibited a singular character: they were stepping stones toward the establishment of the Roman Empire. By way of alliance (foedus) the allied nation would recognize the superior position (majestas) of Rome and possibly submit to a formal restriction of its power to wage a war of its own. These alliances were therefore called "unequal" (foedera iniqua) creating in a dignified form a kind of vassalage. ${ }^{7}$ In addition, the Romans

4. $O p$. cit. supra note 2 , at 16 .

5. It presupposes pristine conditions, as appears from the rule that the feciales, in declaring the war, had to throw a lance into the enemy country.

6. 4 CrCero, Pro Bailbo 15, with an eye to Pompeius, speaks of the praestabilem . . scientiam in foederibus, pactionibus, conditionibus populorum, regum, externarum nationum, in omni denique belli jure ae pacis. This utterance-famous because Grotius borrowed from it the title of his work ON THE LAW OF WAR AND PEACEdoes not imply the existence of anything like a "science" of international law. Cicero simply praises Pompeius for his unusual familiarity with the above-mentioned subjects, representing him as a consummate statesman in foreign affairs.

7. See Arangio-Ruiz, Storia del Diritto Romano 111 (5th ed. 1947) ; Paradisi, Storia Del Diritto INTERnazionale NEL Medio Evo 60 (1940). 
developed a highly characteristic type of surrender (deditio) so precise that only the Roman mind could devise it. It followed the model of "stipulations," that is, formal contracts developed in the practice of Roman private law. The Roman representative would first ask the representatives of the vanquished nation for some preliminary statements (on power of attorney and liberty of disposal) and upon a satisfactory answer would ask them whether their nation was willing to surrender to the Romans the persons and property of their nationals. In the case of an affirmative reply the Roman representative, in the name of the Roman people, would declare his acceptance of the deditio. The vanquished would then ordinarily receive indulgent treatment.

International agreements indicating equality of the participants were not entirely absent. Three times, at 509, 306 and 279 B. C., the Roman Republic entered into treaties with Carthage. ${ }^{8}$ These may be roughly characterized as aiming at the establishment of reciprocal spheres of interest particularly with an eye to commerce, but they differ too much from modern treaties of commerce to be called their predecessors; essentially, they were political in nature. The Roman emperors, however, sometimes concluded commercial agreements with neighboring nations. ${ }^{2}$ Such agreements would open the otherwise closed frontiers at definite places and times for the purpose of commerce. The first treaty of this type which set a pattern for later ones was made in $175 \mathrm{~A}$. D. between the Emperor Marcus Aurelius and the German tribe of the Marcomanni. On the whole, equal treaties did not play any considerable role in the long history of ancient Rome. ${ }^{10}$

Another peculiarity of Roman treaty law was the distinction drawn between an international agreement and its ratification, a prerogative of the Senate. If sworn to, the agreement as such gave rise in the Roman mind to a grave obligation. In case ratification was denied, the Roman negotiator was extradited to the adversary. ${ }^{11}$ The rule, repeatedly followed during Republican times, was probably motivated by a desire to satisfy the gods invoked by the negotiator.

All considered, neither the external municipal nor the international practice of ancient Rome had much to offer to later generations. The expression "unequal treaty" has in modern times often been justly

8. Op. cit. supra note 2 , at 18 .

9. PARAdist, op. cit. supra note 8 , at 336,337 .

10. Italian writers are much concerned with the question to what extent ancient treaties really pertain to "international law" in the modern sense. Cf. Besta, Il diritto intermazionale nel mondo antico in 2 COMMUNICAZIONI E STUDI DELL' INStituto di Diritto Internazionale e Straniero Deti' Università De Milano 9 (1946) ; Paradisi, Studi e opinioni recenti sulla storia del diritto internazionale in 1 RIVISTA ITALIANa PER le Science GIURIDICHe, N. S., 328 (1947). One may doubt the usefulness of such disquisitions.

11. TAEUbler, IMPERIUM RoManUm 10, 112, 114 (1913). 
and vehemently applied to the treaties of the Western powers with the Far Eastern countries which were denied reciprocal concessions, but no recollection of Roman practice was involved there. Perhaps the recent treaties between the Soviet Union and her satellites may bring to mind the unequal alliances of the Romans, but the former differ from the ancient type in that apparently they are drawn in terms of formal equality, whereas in the Roman pattern inequality is frankly admitted. Again, any doctrinal connection between the two historical groups is out of the question. Rather might the type of commercial treaty concluded by the later Roman emperors be considered as having established an historical pattern which has reappeared as they are tied to closed and backward economic systems. The same type can be found in Byzantine practice ${ }^{12}$ and in the Far East. ${ }^{13}$

\section{The Broader Influence}

What has been said so far is somewhat peripheral to the theme of the present article. The real significance of Roman law to the history of international law is indirect only, but in this respect it is farreaching indeed. Treaties and international customs which we have found in Roman practice, but which existed also elsewhere in antiquity, receded in the Middle Ages, dominated as they were by ecclesiastical, feudal and imperial law. Only some vestiges remained, especially in the Mediterranean area. It was not before the Sixteenth and Seventeenth Centuries, when national states definitely emerged as the dominant factors of the historical process, that need for a theory and a theory-conscious practice of international law made itself felt. There was to be a frame of reference for that theory, and in the Western World, exclusive field of budding international law, this could only be the Corpus Juris. No international law, we know, was to be found there, but the great legislative opus offered clear legal conceptions and excellent juristic method. In this situation it was only natural to carry over Roman pronouncements on municipal law to international law, viz., on ownership to territorial sovereignty; on contracts to treaties; on agency (mandatum) to diplomatic missions, etc. Not only did the Corpus Juris enjoy the highest authority in the atmosphere of humanism as ratio scripta, it was the law of the land within the Holy Roman

12. Von Taube, L'apport de Byzance au développement du droit international occidental, 67 REcuEIL DES Cours 233 (Académie du Droit International 1939).

13. The treaties which Russia concluded with China in the Seventeenth and Eighteen Centuries offer some analogy. Cf. MORSE AND MACNAIR, FAR EAstern International ReLations 49 (1901); De Martens, Le confit entre la Russie et la Chirre, 12 Revue de Droit International ET de Législation Comparée 513, 582 (1880). In a broader sense the later "treaty port" arrangements of Western powers with China may be placed in the same category. 
Empire and an important influence in other European territories. Moreover, it was at the bottom of powerful canon law.

Roman law held out a convenient name for the new discipline: jus gentium (law of nations, droit des gens). In ancient Roman law, to be sure, that term had a different significance. ${ }^{14}$ It meant first a quasi-cosmopolitan segment of municipal Roman law designed primarily for litigation among or with foreigners; in a broader-as it were, philosophical-sense it meant law common to all or to many nations (for instance, protection of property). It was in the latter sense that jus gentium included rules of international law such as the sanctity of envoys or the captor's right to war booty; in fact, international law is to a great extent necessarily "universal." The famous Jesuit, Francesco Suarez (1548-1617), ${ }^{15}$ was the first to see clearly that the term jus gentium had come in post-Roman times to mean two different things: (1) universal law and (2) international law (though the latter term and the present application of the first term are of later date); but he did not carry through his observation systematically. Only since Hobbes (1588-1679) has the phrase jus gentium been definitely confined to the sphere of international relations. In this significance it has remained popular up to our day though it is more and more being forced into the background by the term "international law" invented by Bentham in 1789 .

Roman law not only supplied the nascent international law with terms and captions, but also imbued it with fertile impulses. In the first place the concept of just war (bellum justum) must be mentioned. ${ }^{16}$ In later Roman history it had vanished owing to its formal and sacramental character, but it was revived as a moral conception by St. Augustine (354-430). According to him only a just war was morally permissible, and such a war must not be begun out of greed for power or out of vindictiveness; only the avenging of injuries suffered could justify it. ${ }^{17}$ This moral conception was bound to assume gradually a quasi legal character when Christian moral theology branched out into rigidly defined casuistry. The beginning of this process was already visible in the work of Thomas Aquinas (1225-1274) who laid down three prerequisites of a just war: (1) auctoritas principis, that is, the ruler's capacity to wage a war-definitely a legal notion; (2) justa causa, that is, a good reason for doing so; (3) recta intentio, that is, a subjective

14. Op. cit. supra note 2 , at 17.

15. Id. at 66.

16. This topic has been treated more fully by the writer in Just War-A Legal Concept? 42 MrCH. I. Rev. 453 (1943); cf. also op. cit. supra note 2, passim.

17. His definition is foreshadowed by that in 1 CrCERo, De OfFICIIs 11,36 (referring to jus feciale). 
righteous intent. Suarez pressed the doctrine further on the legal side though still treating it as a topic of moral theology; but at the same time, and even earlier, secular jurists dealing with international lawBelli (1502-75), Ayala (1548-84), and particularly Gentili (15521608)-employed it for their own purposes. Thereafter "just war" remained a much discussed problem of legal literature up to the Nineteenth Century and beyond. Whatever its value for the modern science of international law, its merit as a procreative factor in its evolution cannot be denied. If war is conceived as a reaction of law against injury done, an investigation of the various kinds of injuries presenting a just cause for war is imperative. Such injury may consist in invading a foreign territory, in breaking a treaty, in offending the dignity of another nation, etc. Hence the elaboration of the causes of just war will inevitably result in laying out a system of international law itself. This aspect of the just war doctrine is startlingly illustrated by the history of Byzantine and Russian civilization: there the just war idea was not adopted, and no conception of a law of nations was evolved. ${ }^{18}$

In addition to the just war conception, Roman law familiarized the early students of international legal relations with another potent notion, natural law. That idea was of Greek origin but was employed by the Corpus Juris and thereby authoritatively stamped as juridically acceptable. It is true that natural law meant to the ancient Romans unenforceable law, a law of lesser dignity, ${ }^{19}$ while in the light of Christian moral philosophy natural law was considered superior to "positive" law. That metamorphosis remains outside our inquiry; suffice it to state that the Roman sources by their reference to natural law yielded another general idea important in the history of international law.

\section{England and the Law of Nations}

Strangely, there is no country which has done more for the utilization of Roman law in international relations than the common law country par excellence, England. This process developed since the time of Queen Elizabeth. Its first indication is an answer which the Queen gave to the Spanish ambassador Mendoza, who had protested on behalf of his Government against Sir Francis Drake's invasion of the waters surrounding the West Indies. Queen Elizabeth replied that "the use of the Sea and Air is common to all, neither can a title to the Ocean belong to any people or private person; for as much as neither Nature nor public use and customs permitteth any possession thereof." 20

18. Op. cit. supra note 2 , at 44 .

19. E. Levy, Natural Law in Roman Thought in 15 Studia ET DocunseNTA Historiae ET JURIS 1, 17 (1949).

20. 2 Camden, The History of the Most Renowned and Victorious Princess Elizabeth, LATE QUEeN OF ENGLAND 255 (1675). 
These reasons and phrases are typical of Roman law. ${ }^{21}$ More important, when in 1584 Mendoza was found to be involved in a plot against the Queen, the English government turned for advice to Gentili, as well as to another "civilian," John Hotman, and it followed their opinion that under the law of nations nothing could be done against the Spanish ambassador except to expel him. The unprecedented course of the English government was momentous indeed. Behind it one finds the great idea that the law is above all human relations; the King of Spain, or his ambassador, or the Spanish nation is just as little exempt from the law as is the Queen of England. But which particular law ought to apply to Anglo-Spanish relations? From any point of view the Roman law recommended itself. The reasons have been stated above. One might find in the choice of Roman law even a kind of courtesy towards Spain-after all, a Latin nation; and citations from The Corpus Juris were customary with Spanish writers. In any event no other choice was open.

The action of the English government greatly influenced the doctrinal history of the law of nations. Evidently that action was one of the impulses which a few years later (1598) caused Gentili to publish, under the title of $O n$ the Law of $W a r,{ }^{22}$ a book that was in fact the first comprehensive treatise on international law. There he relied widely on the Corpus Juris, going so far as to apply, for instance, the specifically Roman idea of "universal succession" which was created for Roman heirs, to the legal effects of conquest, or to the binding force of a treaty in the case of a succession in sovereignty. While perfectly aware that the rules of the Corpus Juris were not written for international relations, he thought that they could be adapted in a considerable number of cases to the needs of the jus naturae et gentium. This view was soon to receive confirmation from high quarters, for in 1609 James I, addressing the Parliament, declared, "I do greatly esteem the Civil Law the profession thereof serving more for general learning, and being most necessary for matters of treaty with foreign nations. . . . It is in a manner lex gentium and maintains intercourse with all foreign nations." ${ }^{23}$ Certainly the King favored Roman law chiefly for the reason

21. See particularly INstitutes 1.1 , "Naturali jure communia sunt omnium haec: aer, aqua profluens, et mare." REIBSTEIN, DIE ANFÄNGE DES NEUEREN NATUR- UND VöLKERRECHTS 227 (1949), asserts that the Queen's statement (reported above only in part) was literally taken from the writings of Fernando Vasquez de Menchaca, legal councillor to Philip II. This would have been shrewd diplomacy indeed on the part of the Queen, but it would not prove, as intended by Reibstein in agreement with a number of modern Spanish writers, that Vasquez de Menchaca was one of the leading international jurists of his day. However, there is no evidence that the Queen's argument was taken from Vasquez.

22. Op. cit. supra note 2 , at 75 .

23. McIlwain, The Political Works of James I 310 (1918). 
that it supported absolutism, but the reasons he did advance are significant because he felt the people to be amenable to them. The ideas of the King were echoed half a century later by Robert Wiseman in his tractate The Law of Laws, or the Excellence of the Civil Law-the "excellence" being found especially in the application of the "Civil Law" to international relations. ${ }^{24}$ A few years earlier, in 1650, Richard Zouche, successor to Gentili in the chair of Professor of Civil Law at the University of Oxford, had expressed his reliance on Roman law in the very title of his important treatise, Juris et Judicii Fecialis, sive Juris inter Gentes et Quaestionum de eadem Explicatio. The system of the treatise, which far surpasses those of his predecessors scientifically, is entirely based on Roman conceptions (status, dominium, debitum, delictum), and the spirit of the "civilian" dominates the work. ${ }^{25}$

Turning to the Eighteenth Century one finds that a thorough knowledge of Roman law was praised as one of the main reasons for the reputation won by Lord Stowell, outstanding English authority on public maritime law. ${ }^{26}$ And as late as 1879 , Lord Phillimore, author of a celebrated treatise on international law, and perhaps the most typically English figure in its literature, was able to say, forgetting his usual moderation: "Roman law may be said to be the most valuable of all aids to a correct and full knowledge of international jurisprudence of which it is indeed, historically speaking, the actual basis." 27 (The relative sentence, too, is exaggerated, as the starting point of international law must rather be found in the Spanish school of moral theology.)

\section{Other Countries}

No other country can boast a similar record. The Netherlands follows at a wide distance. The States General, in a Proclamation of 1599 , involed the Roman law beside the "common law of nations" as a basis for a blockade against Spain. ${ }^{28}$ Grotius often relied on Roman jurists. He professed to attribute great weight to them as they frequently gave the best reasons to establish what belongs to the law of nature, and as they often furnished evidence in favor of that law and of the law of nations. ${ }^{29}$ Hence the rulings laid down by the Romans were

24. He uses Cicero's utterance, supra note 6 , as the motto of his work, in a form giving the impression that Roman law constitutes the scientia heralded by Cicero.

25. Op. cit. supra note 2 , at 118 .

26. See MacDonell and Mason, Great Jurists of the World 519 (1913).

27. 1 ComMentaries upoN International LaW 32 (1879).

28. Van Vollenhoven, The Three Stages in the Evolution of the Law of Nations 3 (1919).

29. De Jure Belui ac Pacis, Prolegomena, § 52. 
not considered by him as authoritative in themselves, but as useful according to their intrinsic or evidentiary value This reservation was set forth earlier by Gentili but it is more pronounced with Grotius who mentioned among his authorities the jurists only behind the Scriptures, the historians and the scholastic theologians. References to the Corpus Juris are more conspicuous with Grotius' distinguished countryman, Cornelis Bynkershoek (Jurisdiction over Ambassadors, 1721; Questions of Public Law, 1737), whose reliance on Roman law was very natural, since the latter was then the common law of the Netherlands. Such a state of things-prevailing as was seen throughout the whole original territory of the Empire-lent itself as a matter of course to citations from, and to analogies with, the Corpus Juris outside the proper province of the latter.

With the emergence of the great codifications towards the turn of the Eighteenth to the Nineteenth Century, the authority of Justinian's legislation began fast to recede. In the field of international law the ebb had begun even earlier with the rise of the new philosophical school of international law. Neither its founder, Christian Wolff (Law of Nations treated according to Scientific Method, 1749) nor its better known propagator, Emerich de Vattel (Droit des Gens, 1765) was versed in the law, much less in the Roman law. Thenceforth Roman law was gradually pushed into the background of international law doctrine while at the same time the fundamental diversity of the basic conceptions of international law from those of private law came more and more to be recognized. Still, all this was a slow process. In 1844, Heffter, professor at the University of Berlin, after having taught nothing but civil law for over two decades, published his European Law of Nations of the Present which was to become for a long period the leading Continental text book on the subject. Lord Phillimore's utterance came even several decades later, but his opinion has not been asserted since.

\section{Remanants of the Influence}

Vestiges of the former affiliation of Roman law with international law are numerous. ${ }^{30}$ To the use of the phrase "law of nations" many other instances may be added. Thus the term "occupation" as applied in international law to the seizure of enemy territory, or a territory not yet under a sovereign, is taken from the Roman "occupatio" which means the appropriation of things, movable or immovable, belonging to no one. The expression "state servitude" stems from the Roman

30. See Triepel, VölKkERRECht UND LANDESRECht 212 (1893); Ago, IL REQUISTTO DELL' EFFECTIVITÀ DELI' OccupazIONe IN DIRITTO INTERNAzionale 43 (1934). 
"servitus" which has nothing to do with slavery but indicates rights of passage and similar easements directly restricting the ownership of a parcel of land. Again "accretion" 31 and "alluvion" occur in the Corpus Juris. Prescription and its types (extinctive, acquisitive, immemorial) are also taken from Roman sources. Postliminium (postliminy) indicated in Roman law the legal position of a person or a thing that through capture in war had become the property of the enemy but had been, or was, returned to Roman territory; such persons or things regained their former status as if the capture had not occurred-another conception utilized to some extent by modern international law.

With the adoption of a Roman term a certain influx of the ideas back of it was bound to take place, but for the most part (e.g., with respect to servitus and postliminium) they were thoroughly transmuted in the new climate. It is therefore difficult to lay the finger upon definite norms of Roman law which have been actually incorporated in modern international law. One might point to the rule that in the occupation of newly discovered lands title is acquired only by taking possession of them; or to the ipso facto enlargement of territorial sovereignty through alluvion or other kinds of natural accretion; or to the basic idea of extinctive prescription according to which a claim is definitely barred by lapse of time. Perhaps all this does not amount to very much, but it means at least that in some places Roman law served to fasten the shifting sands of international law. The historic significance of Roman law is far greater; it was an indispensable tool in the early development of a doctrine of international law.

31. Though only in the verbal form accrescere. Digest 19.1.13.14. 